\title{
Public procurement and innovation
}

\section{Roberto Caranta ${ }^{1} \cdot$ Pedro Cerqueira Gomes $^{2}$}

Accepted: 6 July 2021 / Published online: 19 July 2021

(c) The Author(s) 2021

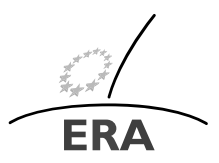

EUROPAISCHE RECHTSAKADEMIE

\begin{abstract}
Innovation has come to the forefront of EU public procurement. Directive 2014/24/ EU has given contracting authorities in the Member States a new award procedure to pursue innovation, namely the innovation partnership. Still a number of issues remain open, notably concerning the allocation of intellectual property rights that may call for the application of State aids rules. Further guidance is thus expected from the Commission.
\end{abstract}

Keywords Procurement · Innovation · Research

\section{Introduction}

Innovation has come to the forefront of EU public procurement. The Europe 2020 strategy for smart, sustainable and inclusive growth set out a vision of Europe's competitive social market economy that "rests on three interlocking and mutually reinforcing priorities: developing an economy based on knowledge and innovation; promoting a low-carbon, resource-efficient and competitive economy; and fostering a high-employment economy delivering social and territorial cohesion". ${ }^{1}$

${ }^{1}$ Commission, Europe 2020, A strategy for smart, sustainable and inclusive growth, $\operatorname{COM}(2010) 2020$ final 3.3.2010.

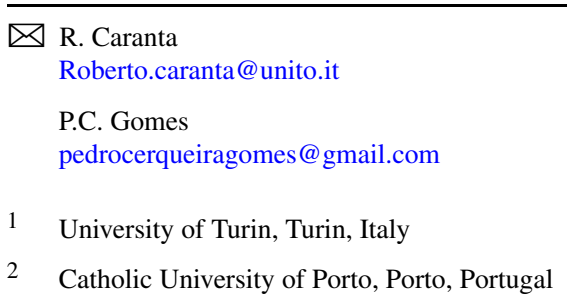


Research and development (R\&D) was identified as a key driver for achieving the objectives of smart, sustainable and inclusive growth. ${ }^{2}$

Public procurement too was expected to play a key role in that strategy, being called upon to improve framework conditions for business to innovate, support the shift towards a resource efficient and low-carbon economy, and improve the business environment, especially for innovative SMEs. The Commission Communication 'Innovation Union', one of the Europe 2020 flagship initiatives, called on Member States "to set aside a part of their procurement budgets for research and innovation" and informing "that the Commission will provide guidance and support mechanisms for contracting authorities". 3

These indications were fully taken on board by the 2011 Commission's "Green Paper on Modernisation of EU Public Procurement Policy" which prepared the ground for what was to be the reform of the 2014 Procurement and Concessions Directives. ${ }^{4}$ Describing a new approach to what has since been labelled 'strategic public procurement', the Green Paper indicated that a complementary objective of the reform was

"to allow procurers to make better use of public procurement in support of common societal goals: These include protection of the environment, higher resource and energy efficiency and combating climate change, promoting innovation and social inclusion, and ensuring the best possible conditions for the provision of high quality public services".

Chapter 4 of the Green Paper was thus dedicated to strategic public procurement, including innovation, with a subsection ${ }^{5}$ specifically dedicated to innovation.

In this regard, Recital 47 of Directive 2014/24/EU has taken on board the rationales for fostering innovation in, and with, public procurement:

"Research and innovation, including eco-innovation and social innovation, are among the main drivers of future growth and have been put at the centre of the Europe 2020 strategy for smart, sustainable and inclusive growth. Public authorities should make the best strategic use of public procurement to spur innovation. Buying innovative products, works and services plays a key role in improving the efficiency and quality of public services while addressing major societal challenges. It contributes to achieving best value for public money as well as wider economic, environmental and societal benefits in terms of generating new ideas, translating them into innovative products and services and thus promoting sustainable economic growth".

On this basis, and recalling the guidance already given by the Commission concerning pre-commercial procurement, which will be discussed later, the recital indicates the need to facilitate the procurement of innovation.

\footnotetext{
${ }^{2}$ See also Commission, Framework for state aid for research and development and innovation, COM(2014) final 21.5.2014, 3 .

${ }^{3}$ Commission, Europe 2020, Flagship Initiative. Innovation Union Brussels, SEC(2010) COM(2010) 546 final, 6.10.2010, 1161.

${ }^{4}$ Commission, Green Paper on the modernisation of EU public procurement policy: Towards a more efficient European Procurement Market Brussels COM (2011) 15 final, 27.1.2011, point 4.3.

${ }^{5}$ Section 4.3 .
} 
Against the background of this policy framework, the present article will start with a short history of EU public procurement and innovation (see Sect. 2). The EU rules on research and procurement will then be introduced (see Sect. 3). Precommercial procurement, which was already allowed, with caveats, under the older directives will be analysed next (see Sect. 4), followed by an examination of the new ad hoc procedure introduced in 2014 - the innovation partnership (see Sect. 5). How innovation considerations may be inserted in the different procurement phases (see Sect. 6). Finally, ownership of intellectual property issues and compliance with state aid rules will be analysed (see Sect. 7) before short conclusions are presented on the above-mentioned next steps in innovation and procurement (see Sect. 8).

\section{Innovation and EU public procurement procedures - a brief story}

After the 2004 Directives, it was undeniable that the association between procurement and innovation encompassed two different, yet complementary approaches from the EU: (1) the public procurement of innovation solutions (PPI) - a category of procurement whereby contracting authorities, through available public procurement procedures, act as a "launch customer" for innovative goods or services that are not yet available on the market, which may include conformance and testing; and (2) precommercial procurement - the procurement of R\&D services, where the research and development phase and the purchasing phase are almost separated. ${ }^{6}$ The latter is excluded from the Procurement Directives and there is specific guidance from the Commission on how to implement it. $^{7}$

This EU strategy for innovative public procurement proved to be ineffective, or at least insufficient. The Innovation Union flagship initiative, issued by the European Commission following the Europe 2020 strategy recognised that public procurement was falling in its role as an innovation driver. ${ }^{8}$

The Commission's “Green Paper on Modernisation of EU Public Procurement Policy" which launched the effort culminated in the 2014 Procurement Directives, began by mentioning that every public procurement procedure should be able to facilitate innovative public purchases. ${ }^{9}$ However, the same working document also mentioned the difficulties contracting authorities were facing when promoting innovation through public procurement, ${ }^{10}$ namely the protection of intellectual property rights, the difficulties in complying with the EU principles of equal treatment and transparency during the dialogue and negotiation phases, the lack of knowledge of public

\footnotetext{
${ }^{6}$ Cerqueira Gomes, EU Public Procurement and Innovation - the Innovation Partnership procedure and Harmonization Challenges (EE, 2021), p. 11.

${ }^{7}$ Commission, Pre-commercial Procurement: Driving innovation to ensure sustainable high quality public services in Europe, COM (2007) 799 final. Cerqueira Gomes, n. 9, p. 11.

${ }^{8}$ Commission, Europe 2020, Flagship Initiative. Innovation Union Brussels, SEC(2010) COM(2010) 546 final, 6.10.2010, point 3.2.

${ }^{9}$ Commission, Green Paper on the modernisation of EU public procurement policy Towards a more efficient European Procurement Market Brussels COM (2011) 15 final, 27.1.2011 COM(2011) 15 Final, point 4.3 .

${ }^{10}$ Caranta, "Commentary on Article 31 Directive 2014/24/UE" in Steinicke and Vesterdorf (eds.), Brussels Commentary on EU Public Procurement Law, CH Beck, Hart and Nomos (2018), pp. 420-428.
} 
officials and the risk aversion of contracting authorities. On this basis, it indicated that more attention should be paid to the contract execution phase and measuring performance in innovative public purchases. In addition, the Commission also stressed that one of the main reasons for reforming the rules on procedures was to allow more flexibility (i.e., discretion) in their use. ${ }^{11}$

These difficulties led the European legislature to insert a new procedure in the 2014 Directives specially designed for the procurement of innovation, regarding goods, services and works - the innovation partnership procedure. Nonetheless, the specific inclusion of the innovation partnership by no means suggest that this is the only procedure that is capable of promoting innovation. In fact, as is recognized in the Guidance on Innovation Procurement, innovation can occur through both open or restricted procedures (mostly through preliminary market consultations; technical specifications; functional requirements; variants; an award phase and so on); through special procedures - mainly negotiated procedures with competition, competitive dialogue, design contest and innovation partnerships; and even without any procurement procedure - that is, through pre-commercial procurement. ${ }^{12}$

Also Article 2(1)(22) provides for a definition of 'innovation' which means "the implementation of a new or significantly improved product, service or process, including but not limited to production, building or construction processes, a new marketing method, or a new organisational method in business practices, workplace organisation or external relations inter alia, with the purpose of helping to solve societal challenges or to support the Europe 2020 strategy for smart, sustainable and inclusive growth".

\section{Research and innovation}

Research is the mother of all innovation, but not all research is the same under EU public procurement law.

Following the approach of previous directives, Article 16(f) of Directive 2004/18/ EC listed among the service contracts excluded from the scope of application of the Directive "research and development services other than those where the benefits accrue exclusively to the contracting authority for its use in the conduct of its own affairs, on condition that the service provided is wholly remunerated by the contracting authority".

The idea is that only research benefiting exclusively the contracting authority, without any wider societal impact, falls within the scope of EU public procurement law. According to the Commission's Framework for state aid for research and development and innovation, this situation can be described as 'exclusive development'. ${ }^{13}$

\footnotetext{
${ }^{11}$ European Commission, Modernising European public procurement to support growth and employment Press Release (2011) IP/11/1580, pp. 1-3.

${ }^{12}$ European Commission, Guidance on Innovation Procurement" COM(2018) 3051 final, 15 May 2018, pp. 4-9.

${ }^{13}$ Commission, Framework for state aid for research and development and innovation, $\operatorname{COM}(2014)$ final 21.5.2014, 3, point 15: (i): “exclusive development' means the public procurement of research and development services of which all benefits accrue exclusively to the contracting authority or contracting entity, and which it may use in the conduct of its own affairs on condition that it fully remunerates them".
} 
The relevant case so far is Azienda Sanitaria Locale di Lecce, concerning a consultancy contract concluded, without any prior call for tenders, between the ASL and the University, and relating to the study and the evaluation of the seismic vulnerability of hospital structures in the province of Lecce. ${ }^{14}$ The study was to contain, in respect of each building concerned, (a) the identification of the structural typology of the materials used for construction and the methods of calculation adopted; with a brief verification of the state of affairs in the light of the project documentation made available; (b) the verification of the soundness of the structure; with a brief analysis of the overall seismic resistance of the building; where appropriate, on-site analysis of structural elements or subsystems that are significant for the purposes of identifying overall seismic resistance; and (c) the compilation of the results referred to under the previous letter, and drafting of technical data sheets on structural diagnosis. The contract was challenged by the body representing engineers and architects claiming that it should have been put out for tenders, and unsuccessfully defended by the contracting authorities as an instance of public-public cooperation excluded from the scope of application of the Directive. Advocate general Trstenjak observed that, while the first criterion in Article 16(f) of Directive 2004/24/EC was satisfied, it was however unclear whether the other requirements were fulfilled. According to her analysis,

"Even though under the consultancy contract ownership of any results produced by the experimental work was to lie with Lecce ASL, it was under a commitment to make express mention of the Department if the results appeared in academic publications. That raises the question of the extent to which the benefits of the research accrue exclusively to Lecce ASL. It cannot be ruled out entirely that that was the case. In the absence of more precise factual information on the content of the agreement and the associated legal consequences under national law, it is not possible to determine with any certainty whether that requirement of the exception in Article 16(f) of Directive 2004/18 is satisfied". 15

It is unfortunate that the referring court did not even consider the applicability of Article 16(f) so that the Court of Justice did not even consider the problem. Clearly, if the mere possibility of publishing some of the results of the research were to defeat the applicability of EU public procurement rules, those rules would apply very seldom, possibly only when those results covered sensitive information the contracting authority did not want to be disclosed.

To avoid this outcome, Recital 35 of Directive 2014/24/EU, based on the consideration that the co-financing of research and development (R\&D) programmes by industry sources should be encouraged, indicates

"that this Directive applies only where there is no such co-financing and where the outcome of the R\&D activities go (sic) to the contracting authority concerned. This should not exclude the possibility that the service provider, having carried out those activities, could publish an account thereof as long as the contracting authority retains the exclusive right to use the outcome of the research

\footnotetext{
${ }^{14}$ Case C- 159/11, Azienda Sanitaria Locale di Lecce and Università del Salento v Ordine degli Ingegneri della Provincia di Lecce and Others (EU:C:2012:817).

${ }^{15}$ Ibid, para. 56.
} 
and development in the conduct of its own affairs. However fictitious sharing of the results of the research and development or purely symbolic participation in the remuneration of the service provider should not prevent the application of this Directive".

Directive 2014/24/EU has somewhat turned upon its head the approach followed up to then, expressly providing in Article 14 for covered research and development contracts. Still, the two conditions pertaining to consideration and ownership of the results are once more triggering the application of EU public procurement law. Contracts covered under Article 14 entail, similarly to those specific to Pre-Commercial Procurement (PCP), a separation of the research and development phase from any deployment of commercial volumes of end-products. However, unlike in PCP, procurement under Article 14 is characterised by the fact that "the public buyer reserves for itself all the benefits of the research (including all intellectual and property rights) for which it pays, alone, the relevant remuneration". ${ }^{16}$

\section{The difficulties with pre-commercial procurement}

According to the Framework for state aid for research and development and innovation, 'pre-commercial procurement' means the public procurement of research and development services where the contracting authority or contracting entity does not reserve all the results and benefits of the contract exclusively for itself for use in the conduct of its own affairs, but shares them with the providers under market conditions. The contract, the object of which falls within one or several categories of research and development defined in this framework, must be of limited duration and may include the development of prototypes or limited volumes of first products or services in the form of a test series. The purchase of commercial volumes of products or services must not be an object of the same contract. ${ }^{17}$

Pre-commercial procurement has therefore several limitations, since the development phase and the purchasing phase are almost separated. Thus, pre-commercial procurement can only include the purchase of a limited set of the first products/solutions, but not large commercial volumes of the developed product/solutions.

According to the Commission staff working document, it is only when the precommercial procurement process starts with prototyping, or even with the development and testing of the first product, contracting authorities may become the owners of products covered by the contract, if the value of the acquired products does not outweigh the value of the research and development services covered by the contract. ${ }^{18}$ It has been argued that this separation between phases was contravening competition and therefore failed to attract new economic operators, especially as participating in

\footnotetext{
${ }^{16}$ See Baciu, "Comment to Article 14", in R. Caranta and A. Sanchez Graells (eds.), Commentary to Directive 2014/24/EU, Elgar Publishing, (2021), forthcoming.

${ }^{17}$ Commission, Framework for state aid for research and development and innovation, $\operatorname{COM}(2014)$ final 21.5.2014, 3, point 15 .

${ }^{18}$ Commission, Pre-commercial Procurement: Driving innovation to ensure sustainable high quality public services in Europe, COM (2007) 799 final, point 3.
} 
a separate, advertised call to compete only for the purchase phase, would give the economic operators that had previously engaged in the development phase an undeniable competitive advantage in the purchasing phase when compared to those who participated only in the latter phase. ${ }^{19}$

Since the Commission does not exclude pre-commercial procurement from state aid rules, pre-commercial procurement can only escape the state aid legal framework when the market-benchmarking criterion is met and the 'price paid for the relevant services reflects the market value of the benefits received by the public purchases and the risk taken by the participant providers'.20

Or, as the Commission suggests, a competitive procurement procedure is had, designed to exclude State aid, by "organising the risk-benefit sharing and the entire procurement process in a way that ensures maximum competition, transparency, openness, fairness and pricing at market conditions enables the public purchaser to identify the best possible solutions the market can offer". ${ }^{21}$

This sounds very well, but surreptitiously brings pre-commercial procurement under the EU general principles of public procurement if not under the directives themselves, forcing contracting authorities to organise two procedures, one for research and development and one for acquisition. Given these restrictions on the use of precommercial procurement, the EU clearly needed other tools to increase the promotion of innovation through public procurement legal framework. ${ }^{22}$

\section{A specific public procurement procedure for innovation - the innovation partnership}

The 2014 Directives have provided for a new tailor-made procurement procedure, the innovation partnership, which is specifically designed and structured for supporting innovation. Recital 49 of the 2014/24/EU Directive stressed that the former procedures available under the repealed 2004 Procurement Directive were not suitable for conducting an innovative public purchase. So, when contracting authorities need both to develop and purchase solutions that are not available on the market (i.e., innovative solutions), they must have access to a specific new procedure, the innovation partnership. In line with the toolbox approach favoured by the Council and the Parliament and which has made its way into Article 26 of Directive 2014/24/EU, the innovation partnership, as all the other procedures foreseen in the Directive, must be implemented into the domestic law of the Member States and be available to the contacting authorities when the stipulated conditions are present.

More specifically, under the first phrase of Article 31(2) of Directive 2014/24/EU, "the innovation partnership shall aim at the development of an innovative product, service or works $[\ldots]$ ”.

\footnotetext{
${ }^{19}$ Arrowsmith, The Law of Public and Utilities Procurement, vol I 3rd edn, Sweet \& Maxwell (2014), pp. 1046-1050.

${ }^{20}$ Commission, Framework for State aid for research and development and innovation, OJ C198/1, para 33 .

${ }^{21}$ Commission, Guidance on Innovation Procurement, COM(2018) 3051 final, 799 final.

${ }^{22}$ Cerqueira Gomes, n. 9, pp. 3-45.
} 
The innovation partnership involves three different phases. The first is a pure procedural phase. This encompasses the conduct of an innovation partnership award procedure under the Directive to choose the partner or partners that will participate in the innovation phase under the contract awarded at the end of the procedure. During the first phase, the legislature adopts a more flexible approach regarding the selection of candidates in Article 31(6) Directive 2014/24/EU as compared with the formula in Article 58(4) Directive 2014/24/EU. Article 31(6) Directive 2014/24/EU provides that in the selection phase, contracting authorities should pay special attention to the candidates' capacity in the field of research and development of innovative solutions. In assessing a tenderer's technical and professional ability to participate in an innovation partnership procedure, these should be the paramount criteria, rather than other elements set out in Article 58(4) of Directive 2014/24/EU, such as the level of experience of economic operators. ${ }^{23}$ Furthermore, the award criterion under the first phase of the innovation partnership procedure must always be the most advantageous tender and the award must be made on the sole basis of the best price-quality ratio, which is the most suitable for comparing tenders for innovative solutions (see Recital 49 of Directive 2014/24/EU).

The second step is the innovation/contract execution phase. This phase aims to develop the proposed innovative goods, services or works, and starts after the award of the contract in the first phase. Thus, the innovation will be developed in the second phase as a matter of the execution of the contract. The contract execution phase is regulated under Article 31(2) and (7) of Directive 2014/24/EU, which has introduced a new approach. Thus, Article 31(2) includes a mandatory requirement to structure the partnership in successive phases and to set intermediate targets to be achieved by the partner or partners, which are true obligations of result. ${ }^{24}$ However, several legal issues remain unsolved by the wording of the Directives, namely how Article 72 (concerning contract modifications) should apply to the innovation partnership or even to state aid rules. ${ }^{25}$

Finally, the third phase is the acquisition phase. This encompasses the placing of orders for the purchase of the results of the innovation phase conducted between the contracting authority and the chosen partners or partners. This is also part of the contract execution phase.

The combination of the development phase and the purchase of large volumes is a crucial distinguishing element of the innovation partnership procedure. First, it marks a difference from the regime applicable to pre-commercial procurement, where the development and purchasing of large volumes is done in separated procedures. Second, this feature also distinguishes the innovation partnership from the competitive procedure with negotiation and competitive dialogue, which are also used for

\footnotetext{
${ }^{23}$ For more developments see Cerqueira Gomes, n. 9, pp. 172-177; Telles and Butler, "Public Procurement Award Procedures in Directive 2014/24/EU", in F Lichère, R Caranta and S Treumer (eds.), Modernising Public Procurement: The New Directive, Djof Publishing (2014), pp. 164-165; Cerqueira Gomes, "The Innovation Partnership under the 2014 Directives", 4 Public Procurement Law Review, (2014), pp. 211-218.

${ }^{24}$ For more developments on the concept of successive phases and intermediate targets see Cerqueira Gomes n. 9, pp. 180-200.

${ }^{25}$ Cerqueira Gomes n. 9, pp. 187-200.
} 
procuring innovative solutions (see Article 26(4)(a)(ii) Directive 2014/24/EU). ${ }^{26}$ In the competitive dialogue, the development/innovation phase occurs during the dialogue phase (see Article 30 of Directive 2014/24/EU), i.e., before the award of the contract, so the contract signed after the award will be for delivery of the proposed innovative solution, rather than for its development. As regards the competitive procedure with negotiation (see Article 29 of Directive 2014/24/EU), the main difference is similar to that for the competitive dialogue. Under the competitive procedure with negotiation, the possible development of innovation happens before the award, during the negotiation phase (see Article 29(5) of Directive 2014/24/EU), rather than during the contract execution phase, which is only for the delivery of the proposed innovative solution, rather than its development.

As mentioned elsewhere, the innovation partnership is not a typical procedure, but a partnership. This indicates the emergence of fundamental characteristics when purchasing innovation not necessarily found elsewhere, namely the close cooperation between contracting authorities and economic operators in the innovation process, which occurs more effectively, during the execution phase rather than in the award phase, when stricter procedural rules apply. ${ }^{27}$

A rapid research on TED reveals that reasonable use is being made of innovation partnerships for the purchase of research services, IT and software and more. It might also be overstretched, one such case arguably being the contract notice by University College Dublin which declared that it was

"very interested in meeting with the banking sector to listen to their views of how both parties could work together for mutual benefit. The previous model was to have a branch on site, however our research has shown that this may no longer be attractive to the industry with the growth of online and internet banking services. These services have improved to the point that banks may wish to review their preferences on how to leverage a relationship with UCD. The university would like to hear from the sector and are therefore open to discussions and ideas on how to move this forward whereby UCD will select one bank to work with. To this end the Bursar's Office invites Expressions of Interest from Service Providers to enter discussions with UCD". ${ }^{28}$

One might well wonder why a preliminary market consultation under Article 40 of Directive 2014/24/EU was not had. ${ }^{29}$

Nonetheless, as already indicated, the circumstance that a new procedure has been created does not mean that the other public procurement procedures are not capable

\footnotetext{
${ }^{26}$ In the same vein, Kronke, "Innovation Partnerships - Purpose, Scope of Application and Key Elements of a New Instrument of Strategic Procurement" in G M Racca and C Yukins (eds.), Joint Public Procurement and Innovation - Lessons Across Brooders, Bruytlant (2019); pp. 337-345.

${ }^{27}$ Caranta, "The Changes to the Public Procurement Directives and the Story They Tell About How EU Law Works", 52(2) Common Market Law Review (2015), pp. 394-395; Steinicke, "The Public Procurement Law Rules and Innovation" in Olykke, Hansen and Tvarno (eds.), EU Public Procurement, Modernisation, Growth and Innovation - Discussions of 2011 Proposals for Procurement Directives, Djof Publishing (2012), pp. 259-273.

${ }^{28}$ https://ted.europa.eu/udl?uri=TED:NOTICE:144856-2021:TEXT:EN:HTML\&src=0.

${ }^{29}$ See Dragos, “Comment to Article 40' in R. Caranta \& A. Sanchez Graells (eds.), Commentary to Directive 2014/24/EU, Elgar Publishing, (2021).
} 
of promoting innovative solutions, namely through the use of technical specifications; technical requirements; variants and award criteria. ${ }^{30}$ However, the EU believed that when it comes to promote innovation through public procurement, contracting authorities should have the possibility of using another procedure capable of overcoming certain failures that have previously been identified.

\section{Innovation in different phases of the procurement procedure}

Even when awarding contracts through older award procedures, innovation may be pursued, namely through technical specifications, use of variants or award criteria.

\subsection{Technical specifications and innovation}

EU law allows for two different forms of technical specifications (see Article 42(3) of Directive 2014/24/EU) in procurement documents (see Article 2(1)(13) of Directive 2014/24/EU). Contracting authorities can include technical specifications in the tender documents covering: (1) terms of performance or functional requirements; and (2) references to specific standards. ${ }^{31}$

The Commission Guidance for Innovation Procurement mentions that descriptive technical specifications with reference to international, European or national standards cannot extend beyond what is currently available on the market. Therefore, the market is more likely to offer different and innovative solutions if the technical specifications are set in terms of performance or functional requirements. ${ }^{32}$

Another aspect that is worth mentioning relates to the means of proof of equivalent technical specification, which could help promoting innovation by attracting innovative SMEs and start-ups. The CJEU in the Var case ruled that EU rules regarding the means of proof of equivalent technical specification, require that contracting authorities request that proof at the stage of the submission of the tender. ${ }^{33}$ I have argued elsewhere, that the VAR ruling failed to conduct a proportionality test. The value of the contract and the number of spare parts to be presented with the tender might also be factors to be taken into account. Imposing the burden of including all relevant information in a tender without a proportionality test may have a negative impact on competition and on the possibility to attract innovative SMEs, since only companies with a strong financial capacity would be able to fulfil this requirement. ${ }^{34}$

\footnotetext{
${ }^{30}$ This fact was recognised by Commission, 'Green Paper on the modernisation of EU public procurement policy: Towards a more efficient European Procurement Market' COM (2011) 15 final, and Commission, 'Guidance on Innovation Procurement' COM (2018) 3051 final, 3-48.

${ }^{31}$ Arrowsmith, n. 21, pp. 587-598.

${ }^{32}$ Commission, Guidance on Innovation Procurement, COM(2018) 3051 final, pp. 33-34.

${ }^{33}$ Case-C-14/07 Var Srl (VAR) Azienda Trasporti Milanesi SpA (ATM) v Iveco Orecchia SpA [2018] ECLI:EU:C:2018:568, para 35. For a diferente opinion, see the Opinion of Advocate General Campos Sánchez-Bordona on 28 February 2018 in case C-14/07 Var Srl (VAR) Azienda Trasporti Milanesi SpA (ATM) v Iveco Orecchia SpA [2018] ECLI:EU:C:2018:568, para 63. For more developments, Smith, "At What Stage in a Tender Process Must a Tender Provide Proof that Products which it Proposes to Deliver Are Equivalent to those Defined in the Technical Specifications? Case C-14/17 VAR and ATM" 6 Public Procurement Law Review (2018), NA151-NA154.
}

${ }^{34}$ Cerqueira Gomes, n. 9, p. 164. 


\subsection{The use of variants and innovation}

Variants have been vaguely defined by the CJEU as alternative solutions for meeting certain requirements in technical specifications. ${ }^{35}$ The compatibility of variants with the EU principle of equal treatment was recognised in the Storebaelt case. ${ }^{36}$

The possibility of using variants is expressed in Article 45 of Directive 2014/ 24/EU. Contracting authorities can ask economic operators to submit variants as a mandatory requirement or simply as an option, provided this possibility is clearly mentioned in the tender documents. However, due to the potential impact that the use of variants can have on the subject matter of a contract, Article 45(1) and (3) of Directive 2014/24/EU provide that they must be linked with the subject matter of the contract. ${ }^{37}$ In other words, they cannot be such as to alter the nature of the contract, for instance changing a goods procurement to a service one. ${ }^{38}$

Both recital 48 of Directive 2014/24/EU and the Commission Guidance on Innovation Procurement ${ }^{39}$ mention the importance of using variants when procuring innovation. The reason why may be easily perceived, since the possibility of asking for alternative solutions to those previously established by a contracting authority allows the market to innovate in the use of goods, services or works not yet deemed possible - or known - by public entities. ${ }^{40}$

\subsection{Award criteria and innovation}

The award criteria that most favours innovation is the best price-quality ratio. In accordance with Article 67(2) of Directive 2014/24/EU, the best price-quality ratio can encompass: (1) quality, including technical merit; (2) aesthetic and functional characteristics; (3) accessibility and design for all users; (4) social, environmental and innovative characteristics; (5) organisation, qualifications and experience of staff assigned to perform the contract, where staff quality is relevant to performance of the contract; (6) after-sales and technical assistance; (7) delivery conditions. ${ }^{41}$ Article 67 allows a great degree of discretion regarding how contracting authorities can assess the best price-quality ratio so as to favour innovative solutions.

The lowest price/cost criterion is not suitable for comparing tenders for innovative solutions. To effectively compare proposed solutions based on price, it would be necessary to measure precisely their impact on the market. Of course, if the goods,

${ }^{35}$ Case C-421/01 Traunfellner GmbH v Österreichische Autobahnen- und Schnellstraßen-FinanzierungsAG (Asfinag) [2003] ECLI:EU:C:2003:549, para. 25-28. For further case law developments, see Sánchez Graells, [6] pp. 56-60.

${ }^{36}$ Case C-243/89 Commission of the European Communities v Kingdom of Denmark (Storebaelt) [1993] ECLI:EU:C:1993:257, para 37-38.

${ }^{37}$ Arrowsmith, n. 21, p. 801.

${ }^{38}$ Recital 109 of Directive 2014/24/EU might be used as an analogy.

${ }^{39}$ Commission "Guidance on Innovation Procurement” COM(2018) 3051 final, 15 May 2018, pp. 34-35.

${ }^{40}$ Cerqueira Gomes, n. 9, pp. 165-168.

${ }^{41}$ On the topic Caranta, "Award Criteria under EU Law (Old and New)" in M Comba and S Treumer (eds.), Award of Contract in EU Procurements, Djøf Publishing (2013), pp. 21-38; Faustino, Award Criteria in the New EU Directive on Public Procurement, 23 Public Procurement Law Review (2014), pp. 124-134. 
services or works are really innovative, it would be impossible to accurately compare those solutions based on price only. ${ }^{42}$

\section{Ownership of intellectual property issues and compliance with state aid rules}

Intellectual property rights are very relevant not only in general, but with specific reference to the different tools used to pursue innovation. Those rights are one of the benefits - and possibly the most relevant one - that parties engaged in innovation can derive from their investments.

Prompted by the European Council ${ }^{43}$ and forming part of its new industrial strategy, ${ }^{44}$ on 10 November 2020 the Commission produced an Action Plan on intellectual property with its Communication Making the most of the EU's innovative potential An intellectual property action plan to support the EU's recovery and resilience. ${ }^{45}$

The Communication starts from the consideration that intangible assets such as inventions, artistic and cultural creations, brands, software, know-how, business processes and data are the cornerstones of today's economy. It stresses the "need to further build on our strengths by upgrading the EU's framework, where needed, and putting in place well-calibrated IP policies to help companies capitalise on their inventions and creations, whilst at the same time ensuring that inventions and creations are serving economy and society at large". ${ }^{46}$

So far, EU public procurement law has taken intellectual property somewhat lightly. However, as already indicated, the allocation of intellectual property rights directly impacts on the scope of application of Directive 2014/24/EU, being one of the considerations that may possibly trigger the application of Article 14 (supra $\S 3$ ). Moreover, the allocation of the same rights may bring a contract within the scope of application of EU state aids rules (supra $\S 4$ ).

Directive 2014/24/EU does not by itself clarify how intellectual property rights should be divided between a contracting authority and a contractor. Article 42(1), third phrase generally indicates that "the technical specifications may also specify whether the transfer of intellectual property rights will be required". The third phrase of Article 31(6), concerning specifically innovation partnerships, instead provides that "in the procurement documents, the contracting authority shall define the arrangements applicable to intellectual property rights". Contracting authorities are thus under a duty to regulate the issue in case they have a recourse to an innovation partnership. Here, no indication is given on how intellectual property rights should be distributed.

\footnotetext{
${ }^{42}$ Cerqueira Gomes, n. 9, p. 179.

${ }^{43}$ See the press release at https://www.consilium.europa.eu/en/press/press-releases/2020/11/10/future-euintellectual-property-policy-council-adopts-conclusions/.

${ }^{44}$ See https://ec.europa.eu/commission/presscorner/detail/en/ip_20_416.

${ }^{45}$ Commission, Making the most of the EU's innovative potential - An intellectual property action plan to support the EU's recovery and resilience, $\operatorname{COM}(2020), 25.11 .2020,760$ final.

${ }^{46}$ Ibid, p. 1.
} 
Some indications come from soft law documents. ${ }^{47}$ The 2018 Commission "Guidance on Innovation Procurement" has a specific section devoted to the management of intellectual property rights. ${ }^{48}$ It focuses on the choice of the contracting partner holding those rights. There are two main extreme solutions (with a combination of the two enriching the realm of possibilities) - namely, either the contracting authority or the contractor holding all new intellectual property rights resulting from the project. As is often the case, the Commission plays it safe by indicating that "the first option is the classical option - as the procuring entity pays $100 \%$ of the costs, it is entitled to all results". State aids rules are not mentioned here, but they are clearly lurking in the background: why should you pay $100 \%$ if the contractor retains value above and beyond the consideration? However, this safe arrangement begets harm for innovation and the society at large, as a contracting authority might then hold an exclusive right they are ill equipped - to put it gently - to manage. Instead, as the Commission indicates with strained understatement "in certain circumstances, suppliers may be better placed than public buyers to commercialize the innovations derived from a public procurement, to secure the appropriate protection of the intellectual property, and defend the intellectual property rights in courts". Therefore, leaving intellectual property ownership to contractors might be considered, provided that incentives to innovate are not distorted and that access to markets is not foreclosed. To this end,

"it may be necessary for public buyers to retain - royalty-free - rights to use the innovative solutions. Public buyers may also require the suppliers to license the rights to certain third parties under fair and reasonable market conditions. These arrangements may be necessary in cases of extension or takeover of the project in order to avoid supplier lock-in".

Even this potentially softer stance will not by itself dispel all the state aids issues. If an open (and, it is assumed, restricted) procedure according to (what is now) Directive 2014/24/EU is not followed - and those procedures are hardly suitable for procuring research and development services, if not for any other considerations, because of the difficulties in drafting detailed technical specifications - the Framework for state aid for research and development and innovation states that the Commission will consider that no state aid is awarded to undertakings, not just where the price paid for the relevant procurement services fully reflects the market value of the benefits received by the public purchaser and the risks taken by the participating providers, but also when specific conditions are met. More specifically, (a) the award procedure must be open, transparent and non-discriminatory and based on objective selection and award criteria specified in advance of the bidding procedure; (b) all rights and obligations of the parties, including with regard to intellectual property rights, are made public in advance; (c) there is no preferential treatment in the supply of commercial volumes of the final products or services; and (d) either "all results which do not give rise to IPR may be widely disseminated, for example through publication, teaching or contribution to standardization bodies in a way that allows other undertakings to

${ }^{47}$ Dragos and Racolţa, "Comparing Legal Instruments for R\&D\&I: State Aid and Public Procurement' 12(4) European Procurement \& Public Private Partnership Law Review (2017), p. 408.

${ }^{48}$ Commission, Guidance on Innovation Procurement, COM(2018) 3051 final, 15 May 2018, Sect. 1.6. 
reproduce them, and any IPR are fully allocated to the public purchaser", or "any service provider to which results giving rise to IPR are allocated is required to grant the public purchaser unlimited access to those results free of charge, and to grant access to third parties, for example by way of non-exclusive licenses, under market conditions". 49

The Framework as usual leave the possibility open for Member States of relying on an individual assessment of the terms of the contract between the public purchaser and the undertaking and of notifying those terms in advance to the Commission pursuant to Article 108(3) of the Treaty. But this does not really seem a palatable alternative at least in so far as the arguably rather high thresholds laid down in Article 4(1)(i) of Commission Regulation (EU) declaring certain categories of aid compatible with the internal market in application of Articles 107 and 108 of the Treaty (also known as the Block Exemptions Regulation) are met. More generally, however, procurement will rarely be used to finance the kind of research activities defined in Article 25 of the Block Exemptions Regulation. Indeed, as indicated in Recital 47 thereof, the "aided part of the research project should completely fall within the categories of fundamental research, industrial research or experimental development".

\section{Conclusions}

The Commission's Communication Making the most of the EU's innovative potential - an intellectual property action plan to support the EU's recovery and resilience" seems to attempt to push the boat a bit further. ${ }^{50}$ It stresses the "need to improve the conditions for companies to protect and use IP in public procurement with a view to stimulating innovation and boosting the economy". Further departing from the traditional default position of allocating intellectual property rights with contracting authority, the Communication indicates the "Member States should consider leaving IP ownership to the contractors where appropriate, unless there are overriding public interests at stake or incompatible open licensing strategies in place". 51

The latter indication highlights a novel potential obstacle in leaving intellectual property rights with the contractor. There is the need strike a balance between facilitating access to and sharing of intangible assets while guaranteeing a fair return on investment. ${ }^{52}$ Since the contracting authority - the public sector in general - is paying, there is an argument to say that intellectual property should be shared with everyone. Which would bring us back to the default position of the contractor losing exclusive rights.

\footnotetext{
${ }^{49}$ Commission, Making the most of the EU's innovative potential - An intellectual property action plan to support the EU's recovery and resilience, $\operatorname{COM}(2020), 25.11 .2020,33$.

${ }^{50}$ Commission, Making the most of the EU's innovative potential - An intellectual property action plan to support the EU's recovery and resilience, $\operatorname{COM}(2020), 25.11 .2020$.

${ }^{51}$ Ibid, point 3; see also the Commission, A SME Strategy for a sustainable and digital Europe $\operatorname{COM(2020)}$ 103 final, point 3.

${ }^{52}$ Commission, Making the most of the EU's innovative potential - An intellectual property action plan to support the EU's recovery and resilience, $\operatorname{COM}(2020), 25.11 .2020$, p. 5.
} 
Of course more nuanced positions may well be developed. As announced in the Communication, the Commission intends to clarify the issues related to intellectual property rights in public procurement in a forthcoming update of the guidance on innovation procurement.

Still, tinkering with the policy documents issued so far will not be enough to get beyond somehow the severe state aid approach outlined in the Framework for state aid for research and development and innovation (supra § 7). If that approach is taken as representing the correct implementation of Article 107 TFEU, tinkering will not be possible. The Commission will have to clearly walk back from its previously held position, admitting that Article 107 TFEU can be read differently from what it had claimed before. This is one more attestation to the complicated relationship that exists between EU public procurement law and state aids rules. ${ }^{53}$

Funding Note Open access funding provided by Università degli Studi di Torino within the CRUI-CARE Agreement.

Open Access This article is licensed under a Creative Commons Attribution 4.0 International License, which permits use, sharing, adaptation, distribution and reproduction in any medium or format, as long as you give appropriate credit to the original author(s) and the source, provide a link to the Creative Commons licence, and indicate if changes were made. The images or other third party material in this article are included in the article's Creative Commons licence, unless indicated otherwise in a credit line to the material. If material is not included in the article's Creative Commons licence and your intended use is not permitted by statutory regulation or exceeds the permitted use, you will need to obtain permission directly from the copyright holder. To view a copy of this licence, visit http://creativecommons.org/licenses/by/ $4.0 \%$.

Publisher's Note Springer Nature remains neutral with regard to jurisdictional claims in published maps and institutional affiliations.

\footnotetext{
${ }^{53}$ See Sanchez-Graells, "State aid and EU public procurement: more interactions, fuzzier boundaries' in L. Hancher \& J.J. Piernas López (eds.), Research Handbook on European State Aid Law, 2nd edn, Edward Elgar (2020).
} 